WellBeing International

WBI Studies Repository

2006

\title{
Differential Effects of Sodium and Magnesium Sulfate on Water Consumption by Beef Cattle
}

\author{
A. S. Grout \\ University of British Columbia \\ D. M. Veira \\ Agriculture and Agri-Food Canada \\ D. M. Weary \\ University of British Columbia \\ M. A. G. von Keyserlingk \\ University of British Columbia \\ D. Fraser \\ University of British Columbia
}

Follow this and additional works at: https://www.wellbeingintlstudiesrepository.org/bioche

Part of the Animal Studies Commons, Other Animal Sciences Commons, and the Other Biochemistry, Biophysics, and Structural Biology Commons

\section{Recommended Citation}

Grout, A. S., Veira, D. M., Weary, D. M., von Keyserlingk, M. A. G., \& Fraser, D. (2006). Differential effects of sodium and magnesium sulfate on water consumption by beef cattle. Journal of animal science, $84(5)$, $1252-1258$.

This material is brought to you for free and open access by WellBeing International. It has been accepted for inclusion by an authorized administrator of the WBI Studies Repository. For more information, please contact wbisr-info@wellbeingintl.org.

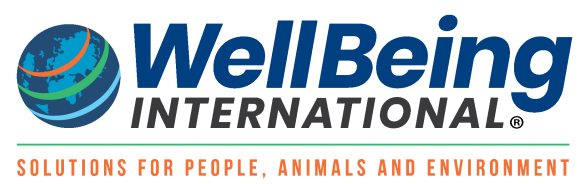




\title{
Differential effects of sodium and magnesium sulfate on water consumption by beef cattle ${ }^{1,2}$
}

\author{
A. S. Grout, ${ }^{3}$ D. M. Veira, $\dagger^{4}$ D. M. Weary, ${ }^{*}$ M. A. G. von Keyserlingk, ${ }^{*}$ and D. Fraser* \\ *Animal Welfare Program, University of British Columbia, Vancouver, BC, Canada V6T 1Z4; and \\ †Agriculture and Agri-Food Canada, Kamloops, BC, Canada V2B 8A9
}

\begin{abstract}
The existing guidelines for maximum sulfate $\left(\mathrm{SO}_{4}\right)$ in cattle drinking water are based on $\mathrm{Na}_{2} \mathrm{SO}_{4}$, although many water sources contain greater concentrations of $\mathrm{MgSO}_{4}$. Two experiments compared the effect of different $\mathrm{SO}_{4}$ salts on water consumption and fecal DM of cattle. In Exp. 1, 8 yearling heifers (initial $\mathrm{BW}=345 \pm 8 \mathrm{~kg}$; mean $\pm \mathrm{SD}$ ) were watered twice daily with tapwater or water containing $\mathrm{Na}_{2} \mathrm{SO}_{4}$ or $\mathrm{MgSO}_{4}$ at target levels of 1,500, 3,000, or 4,500 mg of $\mathrm{SO}_{4} / \mathrm{L}$ for 2 -d treatment periods separated by $2 \mathrm{~d}$ of access to tapwater. In Exp. 2, 16 yearling cattle (initial $\mathrm{BW}=421 \pm 24 \mathrm{~kg}$ ) were watered twice daily with tapwater $\left(16 \mathrm{mg}\right.$ of $\left.\mathrm{SO}_{4} / \mathrm{L}\right)$ or water containing $\mathrm{Na}_{2} \mathrm{SO}_{4}$ at target levels of $2,000 \mathrm{mg}$ of $\mathrm{SO}_{4} / \mathrm{L}$ (low $\mathrm{Na}_{2} \mathrm{SO}_{4}$ ), $\mathrm{MgSO}_{4}$ at 2,000 mg of $\mathrm{SO}_{4} / \mathrm{L}$ (low $\mathrm{MgSO}_{4}$ ), or $\mathrm{MgSO}_{4}$ at 4,000 mg of $\mathrm{SO}_{4} / \mathrm{L}$ (high $\mathrm{MgSO}_{4}$ ) in 21-d treatment periods separated by 7-d periods on tapwater. The first $10 \mathrm{~d}$ of each period were allowed for adjustment to the treat-
\end{abstract}

ment, and the final $11 \mathrm{~d}$ was considered the treatment period for analysis purposes. Treatments were applied in an incomplete Latin square, where each animal was exposed to 3 of the 4 treatments. In Exp. 1, the average daily water consumption decreased linearly as the $\mathrm{SO}_{4}$ concentration increased for $\mathrm{MgSO}_{4}(P=0.0001)$ but not for $\mathrm{Na}_{2} \mathrm{SO}_{4}(P=0.39)$. In Exp. 2 , the average daily water consumption was less for cattle on the high- $\mathrm{MgSO}_{4}$ treatment than for cattle on the low- $\mathrm{MgSO}_{4}$ treatment $(P=0.0001)$, and cattle on the low- $\mathrm{MgSO}_{4}$ treatment tended $(P=0.09)$ to drink less than those on the tapwater treatment. Fecal DM was greater for cattle on the high- $\mathrm{MgSO}_{4}$ treatment than for those on the low$\mathrm{MgSO}_{4}$ treatment $(P<0.01)$. These findings indicate that cattle reduce their consumption of water containing high $\left(\geq 4,000 \mathrm{mg}\right.$ of $\left.\mathrm{SO}_{4} / \mathrm{L}\right)$ concentrations of $\mathrm{MgSO}_{4}$, even after a given time to adjust to the treatment; such reductions may be accompanied by an increase in fecal DM.

Key words: beef cattle, drinking behavior, sulfate, water intake, water quality

(C2006 American Society of Animal Science. All rights reserved.

J. Anim. Sci. 2006. 84:1252-1258

\section{INTRODUCTION}

Cattle grazing on rangeland often drink water that is contaminated with sulfate $\left(\mathrm{SO}_{4}\right)$ salts. Water consumption by cattle begins to decrease at $\mathrm{SO}_{4}$ levels of

\footnotetext{
${ }^{1}$ This project was financially supported by the Beef Cattle Industry Development Fund, the British Columbia Cattlemen's Association, Vancouver Foundation, Agriculture and Agri-Food Canada's Matching Investment Initiative, and the University of British Columbia (Vancouver, BC, Canada).

${ }^{2}$ The authors thank G. Garland, L. Liggins, B. Wheatley, J. Kopp, and the staff of the AAFC Kamloops Range Research Unit for their assistance with experimental procedures and data collection. C. B. Tucker, B. Thompson, and M. Špinka are gratefully acknowledged for their contribution to the preparation of this manuscript.

${ }^{3}$ Current address: University of Cambridge, Department of Zoology, Subdepartment of Animal Behavior, Madingley, Cambridge, UK CB3 8AA.

${ }^{4}$ Corresponding author: veirad@agr.gc.ca

Received June 16, 2005.

Accepted November 22, 2005.
}

2,500 to $3,000 \mathrm{mg} / \mathrm{L}$ (Weeth and Hunter, 1971; Harper et al., 1997) and declines further at greater concentrations (Embry et al., 1959). Over periods of $>7 \mathrm{~d}$, high$\mathrm{SO}_{4}$ water has also resulted in reduced feed consumption, lowered BW gains (Embry et al., 1959; Weeth and Hunter, 1971), scours (Embry et al., 1959), diuresis (Weeth and Hunter, 1971), and suboptimal production (Loneragan et al., 2001). High levels of dietary S, which can result from water containing $\mathrm{SO}_{4}$, have been implicated in reducing net energy values (Zinn et al., 1997), interference with mineral status (Smart et al., 1986; Ivancic and Weiss, 2001), and development of polioencephalomalacia (Olkowski, 1997).

Guidelines for maximum acceptable limits of $\mathrm{SO}_{4}$ in cattle drinking water (CCREM, 1987) are based exclusively on work undertaken with $\mathrm{Na}_{2} \mathrm{SO}_{4}$. However, many water sources contain high levels of $\mathrm{Mg}$ as well as $\mathrm{Na}$, and in these cases, response to the water may be influenced by the cation as well as by $\mathrm{SO}_{4}$. Ruminants have a recognized appetite for $\mathrm{Na}$ (Denton, 1982) and readily consume dissolved $\mathrm{Na}$ salts while avoiding 
comparable concentrations of $\mathrm{Mg}$ salts (Fraser and Reardon, 1980). Sodium is closely linked to thirst mechanisms, but there is no evidence that $\mathrm{Mg}$ plays a role in eliciting or satisfying thirst (Fitzsimons, 1979). Hence, there are good reasons to expect that cattle will respond differently to $\mathrm{Mg}$ than to $\mathrm{Na}$ and that water quality guidelines should distinguish between these cations. The objectives of this work were 1) to determine, using a "taste test" protocol, whether $\mathrm{Na}_{2} \mathrm{SO}_{4}$ and $\mathrm{MgSO}_{4}$ differentially affect water consumption by cattle and 2) to examine whether any such differences, plus differences in fecal DM, would be maintained over a period long enough to incorporate adjustment to treatment.

\section{MATERIALS AND METHODS}

Two experiments took place at Agriculture and AgriFood Canada's Range Research Unit (Kamloops, British Columbia). Average maximum, minimum, and mean daily temperatures during Exp. 1 (August 2 to 29,2001 ) were $28.3,13.5$, and $20.5^{\circ} \mathrm{C}$, and average maximum and minimum relative humidity were 72 and $31 \%$, respectively. There was $0.6 \mathrm{~mm}$ of precipitation during the experimental period, falling as 0.4 and 0.2 $\mathrm{mm}$ on 2 separate days. For Exp. 2 (June 13 to August 28,2002 ), comparable temperatures were 28.7, 13.5, and $20.9^{\circ} \mathrm{C}$, and average maximum and minimum relative humidities were 72.8 and $26.8 \%$, respectively. During this experiment, $36.6 \mathrm{~mm}$ of precipitation occurred, nearly one-half $(17.6 \mathrm{~mm})$ of which fell in July. All experiments and animal use were approved by an institutional animal care committee according to the Canadian Council on Animal Care guidelines (CCAC, 1993).

\section{Exp. 1}

This experiment was carried out as a "taste test" to determine whether yearling beef cattle responded differentially, under short periods of exposure, to 2 common $\mathrm{SO}_{4}$ salt compounds, $\mathrm{Na}_{2} \mathrm{SO}_{4}$ and $\mathrm{MgSO}_{4}$, at equal concentrations of $\mathrm{SO}_{4}$ up to $4,500 \mathrm{mg} / \mathrm{L}$.

\section{Animals and Management}

Eight barren yearling Angus heifers (initial BW = $345 \pm 8 \mathrm{~kg}$; mean $\pm \mathrm{SD}$ ) were studied. All heifers had been raised in the same environment with no known previous access to water contaminated with $\mathrm{SO}_{4}$ compounds. Heifers were housed in 2 groups of 4 in dirt floor pens that were $15 \mathrm{~m}$ wide $\times 13 \mathrm{~m}$ deep with concrete flooring in front of the 10-m feedbunk. Each pen had a covered shelter sufficiently large for all heifers to use at the same time.

Animals were fed orchardgrass hay (Dactylis glomerata; mean $=12.6 \% \mathrm{CP}$; DM basis) ad libitum, refreshed twice daily at 0700 to 0800 and 1400 to 1500 . The hay contained $\mathrm{Na}, 0.03 \% ; \mathrm{Mg}, 0.20 \%$; and S, $0.24 \%$ (DM basis). All heifers could eat from the feedbunk at the same time. Animals also had ad libitum access to
Table 1. Intended vs. actual $\mathrm{SO}_{4}$ concentrations for Exp. $1^{1}$

\begin{tabular}{lcccr}
\hline \multirow{2}{*}{ Cation } & $\begin{array}{c}\text { Intended } \\
\mathrm{SO}_{4}\end{array}$ & $\begin{array}{c}\text { Actual } \\
\mathrm{SO}_{4}\end{array}$ & $\mathrm{Na}$ & $\mathrm{Mg}$ \\
\hline \multirow{4}{*}{ None (tapwater) } & 0 & 1.0 & 2.2 & 2.7 \\
$\mathrm{Na}$ & 1,500 & 1,558 & 704 & $2 . \%$ \\
& 3,000 & 3,194 & 1,540 & $2 . \%$ \\
$\mathrm{ng}$ & 4,500 & 4,804 & 2,340 & 2.7 \\
& 1,500 & 1,609 & 2.7 & 418 \\
& 3,000 & 3,305 & 3.5 & 748 \\
& 4,500 & 4,662 & 5.2 & 1,152
\end{tabular}

${ }^{1}$ Values are treatment means based on samples taken at each drinking opportunity from each water container and pooled for each 2-d treatment period.

a Co-iodized stock salt block ( $\mathrm{NaCl}, 99.5 \% ; \mathrm{I}, 200 \mathrm{mg} / \mathrm{kg}$; Co, $100 \mathrm{mg} / \mathrm{kg}$; The Canadian Salt Company Limited, Pointe Claire, QC, Canada) and to a mineral mix (Mg, $2 \%$; $\mathrm{Na}, 10 \%$; Ca, $12 \%$; P, $12 \%$; Zn, $5,000 \mathrm{mg} / \mathrm{kg}$; Cu, $3,000 \mathrm{mg} / \mathrm{kg}$; Co, $30 \mathrm{mg} / \mathrm{kg}$; I, $160 \mathrm{mg} / \mathrm{kg}$; vitamin A, $650,000 \mathrm{IU} / \mathrm{kg}$; vitamin $\mathrm{D}_{3}, 65,000 \mathrm{IU} / \mathrm{kg}$; vitamin $\mathrm{E}$, 650 IU/kg; Trail Blazer 1:1 Range Mineral; New-Life Feeds, Lethbridge, AB, Canada).

Water was provided twice daily, at 1030 to 1200 and 1530 to 1815 , in 80 -L polyethylene containers placed in the feedbunk. During these times, heifers were locked in the back of the pen and then released one at a time to drink from a single container. Containers were emptied every other day, scrubbed, and refilled. At the start of each treatment period (i.e., every fourth day), concentrated primary solutions were prepared gravimetrically with tapwater and ACS grade $(\geq 99.0 \% \mathrm{pu}-$ rity) anhydrous $\mathrm{Na}_{2} \mathrm{SO}_{4}$ or $\mathrm{MgSO}_{4} \cdot 7 \mathrm{H}_{2} \mathrm{O}$ (Anachemia Canada Inc., Lachine, QC, Canada). Treatment solutions were created daily by diluting the primary solutions to the intended $\mathrm{SO}_{4}$ concentration. Solutions were stirred before each drinking opportunity to prevent settling. The $\mathrm{Na}, \mathrm{Mg}$, and $\mathrm{SO}_{4}$ concentrations in the tapwater used to make up treatment solutions were 2.2 , 2.7 , and $1.0 \mathrm{mg} / \mathrm{L}$, respectively (Table 1 ).

\section{Experimental Design and Data Collection}

An experiment was conducted to determine the effects of offering $\mathrm{SO}_{4}$ concentrations of $1,500,3,000$, or $4,500 \mathrm{mg} / \mathrm{L}$ as either $\mathrm{Na}_{2} \mathrm{SO}_{4}$ or $\mathrm{MgSO}_{4}$ in a Latin square design with a $2 \times 3$ factorial arrangement of treatments. A reference treatment of tapwater $(1 \mathrm{mg}$ of $\mathrm{SO}_{4} / \mathrm{L}$ ) was employed. Eight heifers were tested; the first 7 heifers were randomly assigned to treatment without replacement, and the last one was provided a replicate sample for a randomly selected starting treatment. Animals remained on a treatment for $2 \mathrm{~d}$ (a total of 4 drinking opportunities). Each treatment was followed by $2 \mathrm{~d}$ on tapwater to minimize any residual effects between treatments and to ensure that the heifers remained well hydrated. Water consumption at each drinking opportunity was measured to the nearest $1 \mathrm{~L}$. 
Water evaporation from containers was negligible, and all treatments had similar exposure to sun and shade.

Hay samples were taken at each feeding (twice daily) and pooled in 4-d periods. The pooled samples were then analyzed for CP by micro-Kjeldahl (Nelson and Sommers, 1973), for Mg and Na content by flame atomic absorption spectrophotometry (Ivan et al., 1983), and for $\mathrm{S}$ in nitric-perchloric acid digests by inductively coupled plasma atomic emission spectrometry (McBride and Spiers, 2001). Water samples $(50 \mathrm{~mL})$ were taken at each drinking opportunity from each water container and were pooled for each 2-d treatment period across all 8 heifers, yielding one sample per treatment. The water samples were analyzed for $\mathrm{SO}_{4}$ by a turbidimetric method (AOAC, 1990) and for $\mathrm{Na}$ and $\mathrm{Mg}$ content by flame atomic absorption spectrophotometry (Ivan et al., 1983).

\section{Data Analysis}

Water consumption per day was determined by taking mean daily values over the 2-d treatment period, thus yielding a single value per animal on each treatment. Data were analyzed using Proc Mixed of SAS (SAS Inst., Inc., Cary, NC) according to the model:

$$
\mathrm{Y}_{\mathrm{ijk} \mathrm{l}}=\mu+\mathrm{S}_{\mathrm{i}}+\mathrm{D}_{\mathrm{j}}+\mathrm{S}_{\mathrm{i}} \times \mathrm{D}_{\mathrm{j}}+\mathrm{P}_{\mathrm{k}}+\mathrm{H}_{\mathrm{l}}+\varepsilon_{\mathrm{ijk} \mathrm{k}},
$$

where $\mathrm{Y}_{\mathrm{ijkl}}$ is the individual observation, $\mu$ is the overall mean, $\mathrm{S}_{\mathrm{i}}$ is the effect of salt ( $\mathrm{i}=\mathrm{Mg}$ or $\mathrm{Na}$ ), $\mathrm{D}_{\mathrm{j}}$ is the effect of dose $(j=1,500,3,000$, and 4,500$), S_{i} \times D_{j}$ is the effect of the salt $\times$ dose interaction, $P_{k}$ is the effect of period ( $\mathrm{k}=1$ to 6 ; treated as a random effect), $\mathrm{H}_{\mathrm{l}}$ is the effect of heifer ( $l=1$ to 8 ; treated as a random effect), and $\varepsilon_{\mathrm{ijkl}}$ is the residual error term. The procedure included contrast statements, protected with a significant $F$-test for treatment, to test for linear and quadratic effects of dose for each salt.

\section{Exp. 2}

Substantial declines in water consumption over the 2-d treatment periods of Exp. 1, where treatments were applied in a "taste test" manner, suggested that, at least in the short term, cattle responded adversely to water containing $\mathrm{MgSO}_{4}$. The longer treatment periods of this experiment tested whether initial responses to water containing $\mathrm{MgSO}_{4}$ were maintained once cattle were given time to adjust to treatment; emphasis was placed on exploring the relationship among high levels (4,000 mg of $\left.\mathrm{SO}_{4} / \mathrm{L}\right)$ of $\mathrm{MgSO}_{4}$, water consumption, and fecal DM.

\section{Animals and Management}

Sixteen yearling Hereford and Hereford $\times$ Angus steers and bred heifers (initial BW $=421 \pm 24 \mathrm{~kg}$ ) were used, including 8 animals of each sex. All cattle had been raised as part of the same breeding herd and had spent the previous summer with their dams on rangeland where some natural water sources contain high levels of $\mathrm{SO}_{4}$. All animals had previous exposure to water containing $\mathrm{SO}_{4}$ at concentrations ranging from 0 to approximately $5,000 \mathrm{mg} / \mathrm{L}$ as either $\mathrm{Na}_{2} \mathrm{SO}_{4}$ or $\mathrm{MgSO}_{4}$.

Animals were housed in 2 groups, split according to sex, in the same pens described in Exp. 1. Cattle were fed as described in Exp. 1, except that the orchardgrass hay contained a mean of $9.7 \% \mathrm{CP}, 0.03 \% \mathrm{Na}, 0.14 \%$ $\mathrm{Mg}$, and $0.20 \% \mathrm{~S}$ on a DM basis.

Each pen was equipped with Calan headgates (American Calan Inc., Northwood, NH), and each animal was fitted with a neck collar carrying a transponder that corresponded to one specific headgate within the pen. Containers had marks on their sides denoting 2-L increments of volume. Access to water was limited to 2 drinking opportunities daily at 1000 to 1130 and 1630 to 1730 . The length of access during each drinking opportunity was not predetermined; instead, a drinking opportunity was considered to have ended when all cattle had stopped drinking and left the area of the headgates and water containers. Once this happened, headgates were locked and covers were put on the containers to prevent further access to water until the next scheduled drinking opportunity. After each drinking opportunity, water consumption was noted to the nearest $1 \mathrm{~L}$, and containers were refilled to the 30 -L mark with the appropriate water treatment. Containers were emptied, scrubbed, and refilled every second day. Treatment solutions were prepared according to the method described in Exp. 1, but with fresh primary solutions made up every second day.

\section{Experimental Design and Data Collection}

Two animals of each sex were randomly allocated to each of the 4 treatments: tapwater, $\mathrm{Na}_{2} \mathrm{SO}_{4}$ at 2,000 $\mathrm{mg}$ of $\mathrm{SO}_{4} / \mathrm{L}$ (low $\mathrm{Na}_{2} \mathrm{SO}_{4}$ ), $\mathrm{MgSO}_{4}$ at 2,000 mg of $\mathrm{SO}_{4} /$ $\mathrm{L}$ (low $\mathrm{MgSO}_{4}$ ), or $\mathrm{MgSO}_{4}$ at 4,000 $\mathrm{mg}$ of $\mathrm{SO}_{4} / \mathrm{L}$ (high $\left.\mathrm{MgSO}_{4}\right)$. Cattle were adapted to treatments for $10 \mathrm{~d}$ followed by $11 \mathrm{~d}$ of data collection and were provided tapwater for $7 \mathrm{~d}$ in between periods to minimize residual effects. This cycle was repeated for a total of 3 times, so that each animal was exposed to 3 of the 4 potential treatments in an incomplete Latin square design.

Fecal samples were taken by rectal grab sampling on $\mathrm{d} 11$ and 21 of each treatment period at approximately the same time in the morning, before the first drinking opportunity of the day. Large samples (250 to $500 \mathrm{~g}$ ) were mixed thoroughly, and a representative subsample of approximately $60 \mathrm{~g}$ spread in a thin layer was dried at $60^{\circ} \mathrm{C}$ for $48 \mathrm{~h}$.

Hay samples were taken daily, pooled by 21-d treatment period, and then analyzed as in Exp. 1. Water samples $(10 \mathrm{~mL})$ were taken the morning of every second day after containers had been refilled and were pooled according to treatment within animal. Samples 
were analyzed according to the methods outlined for Exp. 1.

Cattle were monitored daily for changes in their health status through visual observation for signs of excessive weight loss and symptoms of polioencephalomalacia such as "star-gazing," head pressing, and loss of coordination (Hamlen et al., 1993; Niles et al., 2000). A review of the literature suggested that cattle similar to those used in this trial can fully recover from $4 \mathrm{~d}$ of water deprivation (Weeth et al., 1967). Therefore, to maintain animal health, daily water consumption was closely monitored, and on the one occasion when an animal failed to consume the offered water for $3 \mathrm{~d}$ ( 6 drinking opportunities), it was offered tapwater and discontinued on that treatment.

Data Analysis. Data were pooled for the last $11 \mathrm{~d}$ of each treatment period to give a single mean daily water consumption value for each animal on each treatment. A mean fecal DM value per animal on each treatment was generated similarly, by pooling data from $\mathrm{d} 11$ and 21 (start and end of treatment period, respectively). Data were analyzed as an incomplete Latin square design using the Proc Mixed procedure of SAS (SAS Inst., Inc.) according to the model:

$$
Y_{i j k}=\mu+T_{i}+P_{j}+A_{k}+\varepsilon_{i j k}
$$

where $Y_{i j k}$ is the individual observation, $\mu$ is the overall mean, $T_{i}$ is the effect of treatment ( $i=1,2,3$, and 4), $P_{j}$ is the effect of period $(j=1,2$, and 3 ; treated as a random effect), $A_{k}$ is the effect of animal ( $k=1$ to 12 ; treated as a random effect), and $\varepsilon_{\mathrm{ijk}}$ is the residual error term.

Because of the incomplete design, each animal was exposed to 3 of the 4 treatments, yielding 12 animals per treatment and 8 animals for each pair-wise comparison of treatments. To reduce the likelihood of spurious significant differences owing to a large number of comparisons, only 3 specific treatment comparisons were tested: 1) tapwater vs. low $\mathrm{MgSO}_{4}, 2$ ) low $\mathrm{MgSO}_{4}$ vs. high $\mathrm{MgSO}_{4}$, and 3) low $\mathrm{Na}_{2} \mathrm{SO}_{4}$ vs. low $\mathrm{MgSO}_{4}$. The first 2 comparisons tested whether $\mathrm{MgSO}_{4}$ affects water consumption and fecal DM of cattle after time is allowed for adjustment to treatment. The low- $\mathrm{Na}_{2} \mathrm{SO}_{4}$ treatment was included as a reference point because $\mathrm{Na}_{2} \mathrm{SO}_{4}$ is the source of $\mathrm{SO}_{4}$ in the majority of previous published work in this area; the final comparison tested the null hypothesis that $\mathrm{MgSO}_{4}$ and $\mathrm{Na}_{2} \mathrm{SO}_{4}$ have similar effects on water consumption and fecal DM at approximately $2,000 \mathrm{mg}$ of $\mathrm{SO}_{4} / \mathrm{L}$.

\section{RESULTS}

\section{Exp. 1}

Actual $\mathrm{SO}_{4}$ concentrations of the test solutions were within $10 \%$ of the intended values (Table 1). Cattle did not respond $(P=0.39)$ to increasing $\mathrm{Na}_{2} \mathrm{SO}_{4}$ concentra-
Table 2. Effect of $\mathrm{Na}_{2} \mathrm{SO}_{4}$ and $\mathrm{MgSO}_{4}$ on water consumption $(\mathrm{L} / \mathrm{d})$ for the 6 treatments in Exp. $1^{1}$

\begin{tabular}{|c|c|c|c|c|c|}
\hline \multirow[b]{2}{*}{ Source } & \multicolumn{3}{|c|}{$\mathrm{SO}_{4}$} & \multirow[b]{2}{*}{$\mathrm{SE}^{2}$} & \multirow[b]{2}{*}{$P$-value ${ }^{3}$} \\
\hline & $\begin{array}{l}1,500 \\
\mathrm{mg} / \mathrm{L}\end{array}$ & $\begin{array}{l}3,000 \\
\mathrm{mg} / \mathrm{L}\end{array}$ & $\begin{array}{l}4,500 \\
\mathrm{mg} / \mathrm{L}\end{array}$ & & \\
\hline $\mathrm{Na}_{2} \mathrm{SO}_{4}, \mathrm{~L} / \mathrm{d}$ & 37.4 & 34.5 & 30.3 & 4.1 & 0.39 \\
\hline $\mathrm{MgSO}_{4}, \mathrm{~L} / \mathrm{d}$ & 39.8 & 28.2 & 12.6 & 4.1 & $<0.001$ \\
\hline \multicolumn{6}{|c|}{$\begin{array}{l}{ }^{1} \text { Eight heifers were used in a Latin square experiment. Salt treat- } \\
\text { ments were mixed in the drinking water, and the heifers were allowed } \\
\text { individual access twice daily. Water consumption periods lasted for } \\
2 \mathrm{~d}(4 \text { drinking opportunities) followed by } 2 \mathrm{~d} \text { of tap water between } \\
\text { periods. } \\
{ }^{2} \text { Pooled SE. } \\
{ }^{3} P \text {-value for linear contrasts. }\end{array}$} \\
\hline
\end{tabular}

tions by changing their water consumption (Table 2 ). However, a negative linear response was apparent $(P=$ 0.0001 ) as the concentration of $\mathrm{MgSO}_{4}$ increased. A wide range was observed in the response of cattle to water containing both $\mathrm{SO}_{4}$ salts; several heifers drastically reduced their water consumption at high $\mathrm{SO}_{4}$ concentrations, but others responded with only modest decreases in consumption. For example, when given water at $4,500 \mathrm{mg}$ of $\mathrm{SO}_{4} / \mathrm{L}$ as $\mathrm{MgSO}_{4}$, average daily water consumption ranged between 3.5 and $31.8 \mathrm{~L} / \mathrm{d}(\mathrm{CV}=$ $79.6 \%$ ). When given water at $4,500 \mathrm{mg}$ of $\mathrm{SO}_{4} / \mathrm{L}$ as $\mathrm{Na}_{2} \mathrm{SO}_{4}$, cattle consumed between 5.0 and $52.3 \mathrm{~L} / \mathrm{d}$ $(\mathrm{CV}=58.2 \%)$.

\section{Exp. 2}

Actual $\mathrm{SO}_{4}$ concentrations in the test solutions were $16,1,958,2,012$, and 4,060 $\mathrm{mg} / \mathrm{L}$ for the tapwater, low$\mathrm{Na}_{2} \mathrm{SO}_{4}$, low- $\mathrm{MgSO}_{4}$, and high- $\mathrm{MgSO}_{4}$ treatments, respectively. The 3 planned pair-wise comparisons showed that average daily consumption of low- $\mathrm{Na}_{2} \mathrm{SO}_{4}$ and low- $\mathrm{MgSO}_{4}$ water was not different $(P=0.61)$; however, consumption of low- $\mathrm{MgSO}_{4}$ water tended $(P=$ 0.092 ; Table 3) to be lower than that of tapwater. Animals consumed only $75 \%$ as much water when provided high- vs. low- $\mathrm{MgSO}_{4}$ water $(P<0.001)$.

Fecal DM content was greater $(P=0.0001)$ for cattle consuming high- $\mathrm{MgSO}_{4}$ water $(16.4 \%)$ than for cattle consuming low- $\mathrm{MgSO}_{4}$ water (12.8\%); this difference was not apparent between any of the other treatments (Table 3). No instances of compromised animal health were recorded during this study. However, one animal was removed from the high- $\mathrm{MgSO}_{4}$ treatment on $\mathrm{d} 10$, after 6 consecutive drinking opportunities where consumption was $<3 \mathrm{~L}$ per drink. Upon receiving tapwater, this animal's average daily consumption rose to $42 \mathrm{~L} / \mathrm{d}$.

\section{DISCUSSION}

The decline in water consumption with rising $\mathrm{SO}_{4}$ levels observed in both Exp. 1 and 2 is consistent with existing literature (Harper et al., 1997; Loneragan et al., 2001). Similarly, the 44 to $57 \%$ decline in water 
Table 3. Effect of $\mathrm{Na}_{2} \mathrm{SO}_{4}$ and $\mathrm{MgSO}_{4}$ on water consumption and fecal DM values in Exp. $2^{1}$

\begin{tabular}{|c|c|c|c|}
\hline Treatment & $\mathrm{SO}_{4}$ & $\begin{array}{l}\text { Avg. water } \\
\text { consumption }\end{array}$ & Fecal DM \\
\hline & $(\mathrm{mg} / \mathrm{L})$ & $(\mathrm{L} / \mathrm{d})$ & $(\%)$ \\
\hline Tapwater & 16 & 42.7 & 13.0 \\
\hline Low $\mathrm{Na}_{2} \mathrm{SO}_{4}$ & 1,958 & 38.9 & 14.4 \\
\hline Low $\mathrm{MgSO}_{4}$ & 2,012 & 39.7 & 12.8 \\
\hline 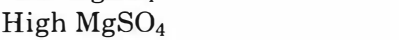 & 4,060 & 29.7 & 16.4 \\
\hline Pooled SE & & 1.5 & 0.7 \\
\hline Preplanned comparisons & & \multicolumn{2}{|c|}{ - $P$-value } \\
\hline Tapwater vs. low $\mathrm{MgSO}_{4}$ & & 0.092 & 0.792 \\
\hline Low $\mathrm{MgSO}_{4}$ vs. high $\mathrm{MgSO}_{4}$ & & $<0.001$ & 0.001 \\
\hline Low $\mathrm{MgSO}_{4}$ vs. low $\mathrm{Na}_{2} \mathrm{SO}_{4}$ & & 0.614 & 0.106 \\
\hline
\end{tabular}

${ }^{1}$ Eight steers and 8 bred heifers were used in a replicated Latin square in which 2 steers and 2 heifers received each water treatment for $21 \mathrm{~d}$ (10 d of adaptation and $11 \mathrm{~d}$ of sample collection) with $7 \mathrm{~d}$ on tapwater between each period. This cycle was repeated 3 times, and each animal was exposed to 3 of the 4 treatments. Therefore, values are based on 12 animals per treatment, and preplanned comparisons were tested using 8 animals per pair. Daily water consumption estimates and fecal values were averaged over the 11-d collection period, resulting in one value per animal for each period.

consumption at high $\mathrm{SO}_{4}$ levels $(\geq 4,000 \mathrm{mg} / \mathrm{L})$ is similar to the reduction in water consumption noted by Weeth and Hunter (1971) at $3,493 \mathrm{mg}$ of $\mathrm{SO}_{4} / \mathrm{L}(35 \%)$ and Harper et al. (1997) at 4,000 $\mathrm{mg}$ of $\mathrm{SO}_{4} / \mathrm{L}(40 \%)$.

Although cattle clearly find $\mathrm{SO}_{4}$ aversive at high levels, the differential response to the associated cation ( $\mathrm{Na}$ vs. $\mathrm{Mg}$ ) appears not to have been reported previously. These experiments demonstrate that $\mathrm{MgSO}_{4}$ and $\mathrm{NaSO}_{4}$ have different effects on the water consumption of cattle as shown by the presence of a dose response to increasing concentrations of $\mathrm{MgSO}_{4}$ and the lack of a similar dose response to increasing concentrations of $\mathrm{Na}_{2} \mathrm{SO}_{4}$ in Exp. 1.

Differences in acceptability between $\mathrm{Na}_{2} \mathrm{SO}_{4}$ and $\mathrm{MgSO}_{4}$ are not surprising given the distinct functions of these ions in the body. Specifically, $\mathrm{Na}$ is the principal extracellular cation (Fitzsimons, 1979), plays an important role in homeostasis, and is involved in active transport through the $\mathrm{Na}^{+} / \mathrm{K}^{+}$pump, whereas Mg plays a critical role in the derivation of energy from ATP (Frandson and Spurgeon, 1992). Differences in palatability of $\mathrm{Na}$ and $\mathrm{Mg}$, as observed in humans (Bruvold and Gaffey, 1969) and moose (Fraser and Reardon, 1980), may contribute to the different responses by cattle. Differences in postingestive consequences (CCREM, 1987) could also play a role in the acceptability of the 2 cations. For example, although both $\mathrm{Mg}$ and $\mathrm{SO}_{4}$ are known purgatives (Harvey and Read, 1973), the effect of $\mathrm{Na}$ is less clear. High levels of $\mathrm{Mg}$ have also been implicated in central nervous system impairment (Fraser et al., 1991).

The unique physiological system that causes a specific appetite for $\mathrm{Na}$ could also affect the acceptability of this cation (Denton, 1982). In some circumstances, $\mathrm{Na}$ appetite might override aversions to high levels of $\mathrm{SO}_{4}$, and although Mg-specific appetite has been sug- gested to occur in the rat, particularly under conditions of deficiency (McCaughey and Tordoff, 2002), it has not yet been demonstrated that this appetite is sufficiently strong to ameliorate $\mathrm{SO}_{4}$ aversion. Bitter taste is an attribute of several compounds including $\mathrm{MgSO}_{4}$ (Frank et al., 2004), and there appears to be large variation in species and individual responses to these bitter substances (Lindemann, 1996). The decrease in consumption of water containing $\mathrm{MgSO}_{4}$ observed in the taste test (Exp. 1) suggests that an aversion to bitterness observed in other species is also prevalent in cattle. In the present studies, because cattle had ample access to $\mathrm{Na}$, no $\mathrm{Na}$ appetite would be expected, but there may still be a tolerance or positive response to $\mathrm{Na}$ that does not occur with $\mathrm{Mg}$. Further, $\mathrm{Na}$ is linked to thirst mechanisms through complex regulatory systems (Fitzsimons, 1979; Blair-West et al., 1989), and animals need to make up both lost water and $\mathrm{Na}$ when they become dehydrated (Rolls and Rolls, 1982).

Of particular interest was the wide variation between animals in response to $\mathrm{SO}_{4}$, regardless of associated cation, suggesting differences in individual aversion thresholds to $\mathrm{SO}_{4}$ in water. Aversion thresholds can be defined as the concentration at which an animal demonstrates that they find a compound to be unpalatable by altering their behavior, either by reducing water consumption or discriminating against it in a preference test (Digesti and Weeth, 1976). Such phenomena have been described elsewhere as taste discrimination (Bell and Williams, 1959), taste quality (Bruvold and Gaffey, 1969), behavioral taste thresholds (Goatcher and Church, 1970a,b), and discrimination and rejection thresholds (Weeth and Capps, 1972). Aversion thresholds are known to vary in humans (Zoeteman, 1980), and similar differences may well occur in cattle. Goatcher and Church (1970a) demonstrated a trend in variability of aversion thresholds in ruminants offered water containing acetic acid, where response varied by as much as $71 \%$ between 2 groups of sheep. Variation in response to $\mathrm{SO}_{4}$ water might also have been influenced by the Calan gates, which can interfere with social interactions (Sowell et al., 1999). At rangeland watering sites where cattle can drink as a group, it is possible that social facilitation (Clayton, 1978; Ralphs and Provenza, 1999) might reduce individual variation in water consumption.

Aversion thresholds for various compounds can be influenced by species, age, sex, physiological status, and diet composition (McKee and Wolf, 1963; Goatcher and Church, 1970b). The influence of these factors can largely be ruled out in these experiments, as the animals were uniform in these characteristics. Previous experience with the compounds in question can also play a role in taste response (Provenza and Balph, 1987), but in these experiments, preliminary analysis suggested that response to $\mathrm{SO}_{4}$ was similar for cattle with and without previous exposure. Bell and Williams (1959) used monozygotic twin calves to demonstrate that aversion thresholds may be genetically controlled. 
Associations of taste with negative postingestive consequences may also be genetically fixed (Fischer, 1967) and, thus, could result in varying aversion thresholds between different genetic lines of cattle; this factor was not controlled in either of the experiments under discussion.

Individual variability in aversion thresholds coupled with small sample size ( $\mathrm{n}=8$ and 16 for Exp. 1 and 2, respectively) might account for the lack of treatment differences at lower (i.e., $\leq 3,000 \mathrm{mg} / \mathrm{L}$ ) $\mathrm{SO}_{4}$ concentrations in both experiments. Once the $\mathrm{SO}_{4}$ concentration increased to approximately $4,000 \mathrm{mg} / \mathrm{L}$, the water became sufficiently unpalatable to elicit a more dramatic rejection. Treatment differences may also have been obscured by an interaction between salinity and thirst. Ingestion of saline water (i.e., containing a surplus of ions) increases the demand for water (Silanikove et al., 1997) and could result in a continuous feedback loop whereby the saline water increased thirst, overriding the low palatability of saline water.

According to the NRC (1996), cattle similar to those used in this research require approximately $41 \mathrm{~L}$ of water daily, depending on animal and environmental factors. This is in close agreement with average daily water consumption values for tapwater in all 3 experiments. At approximately 4,500 $\mathrm{mg}$ of $\mathrm{SO}_{4} / \mathrm{L}$ (Exp. 1), average daily water consumption during the 2 -d treatments dropped well below this level for $\mathrm{Na}_{2} \mathrm{SO}_{4}(30.3$ $\mathrm{L} / \mathrm{d})$ and even lower for $\mathrm{MgSO}_{4}(12.6 \mathrm{~L} / \mathrm{d})$; similarly, in Exp. 2, average daily water consumption at approximately $4,000 \mathrm{mg}$ of $\mathrm{SO}_{4} / \mathrm{L}$ as $\mathrm{MgSO}_{4}$ was only $29.7 \mathrm{~L} /$ $\mathrm{d}$ for the 11-d treatments. Large stores of rumen water (Hecker et al., 1964) and the ability to withstand several days of water deprivation without long-term consequences (Weeth et al., 1967) might have allowed the cattle to maintain low water consumption for the short duration of Exp. 1. Several potential mechanisms could be responsible for the results observed here. A likely scenario is that cattle had time to adapt to both the flavor of water containing $\mathrm{MgSO}_{4}$ and the metabolic consequences of increased $\mathrm{MgSO}_{4}$ intake. Alternatively, the animals might not have adjusted but might have been able to sustain such low consumption over the 21-d periods of Exp. 2 without becoming dehydrated, and the longer treatment periods forced the cattle to increase their consumption of the poor quality water (Weeth and Capps, 1972) despite any metabolic consequences.

It was expected that the purgative properties of $\mathrm{SO}_{4}$ salts, and particularly $\mathrm{MgSO}_{4}$ (McKee and Wolf, 1963; Harvey and Read, 1973; Fraser et al., 1991), would result in an increase in fecal moisture. Embry et al. (1959) observed scouring in cattle given high-SO ${ }_{4}$ water. However, fecal DM content was greater $(P=0.0001)$ in cattle exposed to high $\mathrm{MgSO}_{4}$ compared with low $\mathrm{MgSO}_{4}$ in Exp. 2. When cattle experience water restriction or deprivation, one of the first physiological responses noted is a decrease in fecal water content (Thornton and Yates, 1968; Little et al., 1976). The reduction in water consumption by cattle on the high$\mathrm{MgSO}_{4}$ treatment might have reduced fecal moisture sufficiently to outweigh any purgative effects of $\mathrm{MgSO}_{4}$. Further work investigating the interaction between consumption of purgative salts and decreased water consumption is warranted.

Finally, readers should regard the results of Exp. 1 with some caution, as the animals received treatments in a set order, and the analysis showed an effect of treatment order $(P<0.05)$. However, when these results are considered with those of Exp. 2, in which treatments were applied randomly in the style of a Latin square, it is clear that increasing concentrations of $\mathrm{MgSO}_{4}$ in drinking water can potentially reduce water consumption by cattle.

\section{LITERATURE CITED}

AOAC. 1990. Method 973.57: Sulfate in water-turbidimetric method. Pages 330-331 in Official Methods of Analysis. 15th ed. Assoc. Off. Anal. Chem., Arlington, VA.

Bell, F. R., and H. L. Williams. 1959. Threshold values for taste in monozygotic twin calves. Nature (Lond.) 183:345-346.

Blair-West, J. R., D. A. Denton, M. J. McKinley, and R. S. Weisinger. 1989. Sodium appetite and thirst in cattle subjected to dehydration. Am. J. Physiol. 257:R1212-1218.

Bruvold, W. H., and W. R. Gaffiey. 1969. Evaluative ratings of mineral taste in water. Percept. Mot. Skills 28:179-192.

CCAC. 1993. Guide to the Care and Use of Experimental Animals. Vol. 1. 2nd ed. Canadian Council on Animal Care, Ottawa, ON

CCREM. 1987. Canadian Water Quality Guidelines. Canadian Task Force on Water Quality: Agricultural Uses-Livestock Watering. Canadian Council of Resource and Environment Ministers, Ottawa, ON.

Clayton, D. A. 1978. Socially facilitated behavior. Q. Rev. Biol. 53:373-392.

Denton, D. 1982. The Hunger for Salt. Springer-Verlag, New York, NY.

Digesti, R. D., and H. J. Weeth. 1976. A defensible maximum for inorganic sulfate in drinking water for cattle. J. Anim. Sci. 42:1498-1502.

Embry, L. B., M. A. Hoelscher, R. C. Wahlstrom, C. W. Carlson, L. M. Krista, W. R. Brosz, G. F. Gastler, and O. E. Olson. 1959. Salinity and livestock water quality. South Dakota Agric. Exp. Stn. Bull. 481. South Dakota State Univ.. Brookings.

Fischer, R. 1967. Genetics and gustatory chemoreception in man and other primates. Pages $61-81$ in The Chemical Senses and Nutrition. M. R. Kare and O. Maller, ed. The Johns Hopkins Press, Baltimore, MD.

Fitzsimons, J. T. 1979. The Physiology of Thirst and Sodium Appetite. Cambridge Univ. Press, Cambridge. UK

Frandson, R. D., and T. L. Spurgeon. 1992. Anatomy and Physiology of Farm Animals. 5th ed. Lippincott Williams and Wilkins, Media, PA.

Frank, M. E., B. P. Bouverat, B. I. MacKinnun, and T. P. Hettinger. 2004. The distinctiveness of ionic and nonionic bitter stimuli. Physiol. Behav. 80:421-431.

Fraser, C. M., J. A. Bergeron, A. Mays, and S. E. Aiello, ed. 1991. Systemic pharmacotherapeutics. Page 1382 in The Merck Veterinary Manual. 7th ed. Merck and Co., Inc., Rahway, NJ.

Fraser, D., and E. Reardon. 1980. Attraction of wild ungulates to mineral-rich springs in central Canada. Holarct. Ecol. 3:36-40.

Goatcher, W. D., and D. C. Church. 1970a. Taste responses in ruminants. IV. Reactions of pygmy goats, normal goats, sheep and cattle to acetic acid and quinine hydrochloride. J. Anim. Sci. 31:373-382.

Goatcher, W. D., and D. C. Church. 1970h. Review of some nutritional aspects of the sense of taste. J. Anim. Sci. 31:973-981. 
Hamlen, H., E. Clark, and E. Janzen. 1993. Polioencephalomalacia in cattle consuming water with elevated sodium sulfate levels: A herd investigation. Can. Vet. J. 34:152-158.

Harper, G. S., T. J. King, B. D. Hill, C. M. L. Harper, and R. A. Hunter. 1997. Effect of coal mine pit water on the productivity of cattle. II. Effect of increasing concentrations of pit water on feed intake and health. Aust. J. Agric. Res. 48:155-164.

Harvey, R. F., and A. E. Read. 1973. Saline purgatives act by releasing cholecystokinin. Lancet 2(1):185-187.

Hecker, J. F., O. E. Budtz-Olsen, and M. Ostwald. 1964. The rumen as a water store in sheep. Aust. J. Agric. Res. 15:961-968.

Ivan, M., M. Ihnat, and D. M. Veira. 1983. Solubility and flow of calcium, magnesium and phosphorus in the digestive tract of sheep given maize or alfalfa silages. Anim. Feed Sci. Technol. 9:131-142.

Ivancic, J., and W. P. Weiss. 2001. Effiect of dietary sulfur and selenium concentrations on the selenium balance of lactating Holstein cows. J. Dairy Sci. 84:225-232.

Lindemann, B. 1996. Taste reception. Physiol. Rev. 76:719-766.

Little, W., B. F. Sansom, R. Manston, and W. M. Allen. 1976. Effects of restricting the water intake of dairy cows upon their milk yield, body weight and blood composition. Anim. Prod. 22:329-339.

Loneragan, G. H., J. J. Wagner, D. H. Gould, F. B. Garry, and M. A. Thoren. 2001. Effiects of water sulfate concentration on performance, water intake, and carcass characteristics of feedlot steers. J. Anim. Sci. 79:2941-2948.

McBride, M. B., and G. Spiers. 2001. Trace element content of selected fertilizers and dairy manures as determined by ICO-MS. Commun. Soil Sci. Plant Anal. 32:139-156.

McCaughey, S. A., and M. G. Tordoff. 2002. Magnesium appetite in the rat. Appetite 38:29-38.

McKee, J. E., and H. W. Wolf, ed. 1963. Water Quality Criteria. 2nd ed. Resources Agency of California State Water Resources Control Board, Sacramento, CA.

Nelson, D. W., and L. E. Sommers. 1973. Determination of total nitrogen in plant material. Agron. J. 65:109-112.

Niles, G. A., S. Morgan, and W. C. Edwards. 2000. Sulfur-induced polioencephalomalacia in stocker calves. Vet. Human Toxicol. 42:290-291.

NRC. 1996. Nutrient Requirements of Beef Cattle. 7th ed. Natl. Acad. Press, Washington, DC.
Olkowski, A. A. 1997. Neurotoxicity and secondary metabolic problems associated with low to moderate levels of exposure to excess dietary sulphur in ruminants: A review. Vet. Human Toxicol. 39:355-360.

Provenza, F. D., and D. F. Balph. 1987. Diet learning by domestic ruminants: Theory, evidence and practical implications. Appl. Anim. Behav. Sci. 18:211-232.

Ralphs, M. H., and F. D. Provenza. 1999. Conditioned food aversions: Principles and practices, with special reference to social facilitation. Proc. Nutr. Soc. 58:813-820.

Rolls, B. J., and E. T. Rolls. 1982. Thirst. Cambridge Univ. Press, Cambridge, UK.

Silanikove, N., E. Maltz, A. Halevi, and D. Shinder. 1997. Metabolism of water, sodium, potassium, and chlorine by high yielding dairy cows at the onset of lactation. J. Dairy Sci. 80:949-956.

Smart, M. E., R. Cohen, D. A. Christensen, and C. M. Williams. 1986. The effects of sulfate removal from the drinking water on the plasma and liver copper and zinc concentrations of beef cows and their calves. Can. J. Anim. Sci. 66:669-680.

Sowell, B. F., M. E. Branine, J. G. P. Bowman, M. E. Hubbert, H. E. Sherwood, and W. Quimby. 1999. Feeding and watering behavior of healthy and morbid steers in a commercial feedlot. J. Anim. Sci. 77:1105-1112.

Thornton, R. F., and N. G. Yates. 1968. Some effects of water restriction on apparent digestibility and water excretion of cattle. Aust. J. Agric. Res. 19:665-672.

Weeth, H. J., and D. L. Capps. 1972. Tolerance of growing cattle for sulfate-water. J. Anim. Sci. 34:256-260.

Weeth, H. J., and J. E. Hunter. 1971. Drinking of sulfate-water by cattle. J. Anim. Sci. 32:277-281.

Weeth, H. J., D. S. Sawhne, and A. L. Lesperance. 1967. Changes in body fluids, excreta and kidney function of cattle deprived of water. J. Anim. Sci. 26:418-423.

Zinn, R. A., E. Alvarez, M. Mendez, M. Montaño, E. Ramirez, and Y.Sehen. 1997. Influence of dietary sulfur level on growth performance and digestive function in feedlot cattle. J. Anim. Sci. 75:1723-1728.

Zoeteman, B. C. J. 1980. Sensory Assessment of Water Quality. Pergamon Series on Environmental Science Volume 2. Pergamon Press, Exeter, UK. 